\title{
Penerapan Model Problem Based Learning (PBL) pada Materi Program Linear untuk Meningkatkan Hasil Belajar Siswa
}

\author{
${ }^{1}$ Maria Rosalia Bili \& ${ }^{2}$ Dekriati Ate \\ Program Studi Pendidikan Matematika, STKIP Weetebula, Jl. Mananga Aba, Sumba \\ Barat Daya-NTT, Indonesia \\ Email: bilirosalia@gmail.com
}

$\begin{array}{ll}\text { ARTICLE INFO } & \text { ABSTRACT } \\ \text { Article history } & \text { [Title: The Application of Problem Based Learning (PBL) Models to Linear } \\ \text { Received: March } 2018 & \text { Program Materials to Improve Student Learning Outcomes]. This research is a } \\ \text { Revised: April } 2018 & \text { classroom action research that aims to improve the learning outcomes oflinear programs } \\ \text { Accepted: May } 2018 & \text { through the application of the problem based learning model of class XII students of } \\ \text { Published: June } 2018 & \text { SMA N } 1 \text { Wewewa Utara in the odd semester of the academic year 2017/2018 with } 36 \\ & \text { students. Cycle I was held for } 5 \text { meetings and Cycle II was carried out for } 4 \text { meetings } \\ \text { Keywords } & \text { including the giving of the final test of Cycle I and Cycle II. Data retrieval is done using } \\ \text { Learning outcomes; } & \text { learning outcomes tests and observation sheets. The collected data were analyzed using } \\ \text { PBL; } & \text { quantitative and qualitative analysis. The results of this study indicate that (1) the value } \\ \text { Linear Program } & \text { of classical completeness of learning outcomes of students of class XII IPA of SMA N. } \\ & \text { 1 Wewewa Utara at the end of the first cycle test was 61.11\% with sufficient categories } \\ & \text { while the value of classical completeness of student learning outcomes in cycle II was } \\ & \text { 83.3\% with a very good category and (2) The learning outcomes of students of class XII } \\ & \text { Natural Sciences at SMAN 1 North Wewewa in cycle I to Cycle II increased by 22.19\% } \\ & \text { through the application of the problem based learning model. }\end{array}$

\begin{tabular}{ll}
\hline INFO ARTIKEL & ABSTRAK \\
\hline Sejarah Artikel & Penelitian ini adalah penelitian tindakan kelas yang bertujuan untuk \\
Dikirim: Maret 2018 & meningkatkan hasil belajar program linear melalui penerapan model problem \\
Direvisi: April 2018 & based learning siswa kelas XII IPA SMA N. 1 Wewewa Utara pada semester ganjil \\
Diterima: Mei 2018 & tahun ajaran 2017/2018 dengan jumlah siswa sebanyak 36 orang. Siklus I \\
Dipublikasi: Juni 2018 & $\begin{array}{l}\text { dilaksanakan selama } 5 \text { kali pertemuan dan siklus II dilaksanakan selama } 4 \text { kali } \\
\text { pertemuan termasuk pemberian tes akhir siklus I dan Siklus II. Pengambilan data }\end{array}$ \\
Kata kunci & dilakukan dengan menggunakan tes hasil belajar dan lembar observasi. Data \\
Hasil Belajar; & yang terkumpul dianalisis dengan menggunakan analisis kuantitatif dan \\
PBL; & kualitatif. Hasil penelitian ini menunjukkan bahwa (1) Nilai ketuntasan klasikal \\
Program Linear & hasil belajar siswa kelas XII IPA SMA N. 1 Wewewa Utara tes akhir siklus I \\
& adalah 61,11\% dengan kategori cukup sedangkan nilai ketuntasan klasikal hasil \\
& belajar siswa pada siklus II adalah 83,3\% dengan kategori sangat baik dan (2) \\
& Hasil belajar siswa kelas XII IPA SMAN 1 Wewewa Utara pada siklus I ke Siklus \\
& II mengalami peningkatan sebesar 22,19\% melalui penerapan model problem \\
based learning.
\end{tabular}

How to Cite this Article?

Bili, M.R \& Ate, D. (2018). Penerapan Model Problem Based Learning (PBL) pada Materi Program Linear untuk Meningkatkan Hasil Belajar Siswa. Jurnal Penelitian dan Pengkajian Ilmu Pendidikan: e-Saintika, 1(2), 81-86. 


\section{PENDAHULUAN}

Program linear adalah suatu konsep atau program untuk memecahkan masalah optimasi (maksimum dan minimum) (Dewantara, 2008) yang mengandung kendala-kendala atau batasan-batasan yang dapat diterjemahkan dalam bentuk persamaan dan pertidaksamaan linear (Siswanto, 2005). Jadi, dapat disimpulkan bahwa program linear adalah suatu program dengan model matematika yang terdiri atas persamaan atau pertidaksamaan linear yang diperoleh dari hasil penafsiran atau terjemahan suatu masalah program linear yang bertujuan untuk mengoptimumkan (maksimum atau minimum) nilai suatu fungsi objektif.

Salah satu tujuan pembelajaran matematika tingkat Sekolah Menengah Atas (SMA) dan Madrasah Aliyah (MA) adalah memecahkan masalah yang meliputi kemampuan memahami masalah, merancang model matematika, menyelesaikan model dan menafsirkan solusi yang diperoleh (BSNP, 2006).

Beberapa penelitian terdahulu menunjukkan bahwa program linear merupakan suatu materi matematika yang sulit dipahami oleh siswa. Idris (2015) menyatakan bahwa ada materi prasyarat yang harus dikuasai siswa untuk mempelajari program linear, siswa kadang berdalih mengatakan bahwa materi prasyarat belum dipahami padahal materi itu sebenarnya telah ada di jenjang sebelumnya (SMP). Kiswanto (2016) dalam penelitiannya memberikan penjelasan bahwa siswa masih mengalami kesulitan dalam mengajukan masalah dan menyelesaikan program linear dan model matematika, jika dikaitkan dengan kehidupan sehari-hari. Hal ini relevan dengan penelitian menurut Malau (1996) dalam penelitian Irawati (2014), penyebab siswa mengalami kesulitan, antara lain: kurangnya pemahaman atas materi prasyarat maupun materi pokok yang dipelajari, kurangnya penguasaan bahasa matematika, keliru menafsirkan atau menerapkan rumus, salah perhitungan, kurang teliti dan lupa konsep. Hal ini juga tampak pada saat penulis melakukan wawancara dengan guru matematika dan melakukan tes awal pada siswa kelas XII IPA di SMAN 1 Wewewa Utara. Dari tes awal tersebut terlihat bahwa dari 36 orang siswa, tidak ada satupun siswa yang memperoleh nilai lebih besar sama dengan 75 (KKM) dengan nilai rata-rata 34,71. Hal ini memberikan gambaran bahwa persentase belajar matematika siswa tergolong rendah. Kesulitan yang dialami khususnya pada pokok bahasan program linear itu terkait materi prasyarat dan menerjemahkan soal cerita ke dalam bentuk model matematika yang menyebabkan hasil belajar siswa rendah.

Pendekatan pembelajaran dengan melibatkan siswa secara aktif dengan pola pembelajaran berpusat pada siswa (student-center) yaitu dengan menggunakan model Problem Based Learning (PBL) dapat menjadi solusi pemecahan masalah yang telah diuraikan. Hasil penelitian Prayogi dan Asy'ari (2013) membuktikan model PBL dapat meningkatkan kemampuan berpikir kritis dan hasil belajar siswa pada materi fluida. Dewi (2013) lebih lanjut menyatakan bahwa model PBL dengan blanded learning dapat meningkatkan hasil belajar kognitif, afektif, dan psikomotor siswa. Meilani dkk (2017) yang menerapkan model PBL dengan pendekatan saintifik menemukan hal sepupa yaitu meningkatnya hasil belajar siswa, sedangkan Sukaisih dan Muhali (2014) menyatakan model pembelajaran problem solving yang memiliki karakter serupa dapat meningkatkan hasil belajar dan 
kesadaran metakognitif siswa. Penelitian ini bertujuan untuk meningkatkan hasil belajar siswa melalui penerapan model PBL pada materi program linier.

\section{METODE}

Penelitian ini menggunakan Penelitian tindakan Kelas (PTK). Subjek penelitian ini adalah siswa kelas XII IPA SMAN 1 Wewewa Utara dengan jumlah siswa 36 orang siswa terdiri dari 9 siswa laki-laki dan 27 orang siswa perempuan. Teknik pengumpulan data menggunakan teknik tes dan non tes. Pengumpulan data dilakukan melalui tes tertulis dan lembar observasi. Tes tertulis digunakan untuk mengetahui hasil belajar kognitif siswa. Lembar observasi digunakan untuk mengamati kinerja guru. Adapun teknik analisis datanya menggunakan teknik analisis data secara kuantitatif untuk data hasil belajar siswa dan teknik analisis data secara kualitatif untuk data lembar observasi guru. Penelitian ini merupakan Penelitian Tindakan Kelas (PTK) yang dilaksanakan dalam 2 (dua) siklus, masingmasing siklus dilaksanakan dalam 4 (empat) tahap, yaitu perencanaan, tindakan, pengamatan, dan refleksi. Prosedur kerja tersebut secara garis besar dapat dijelaskan pada Gambar 1 di bawah ini.
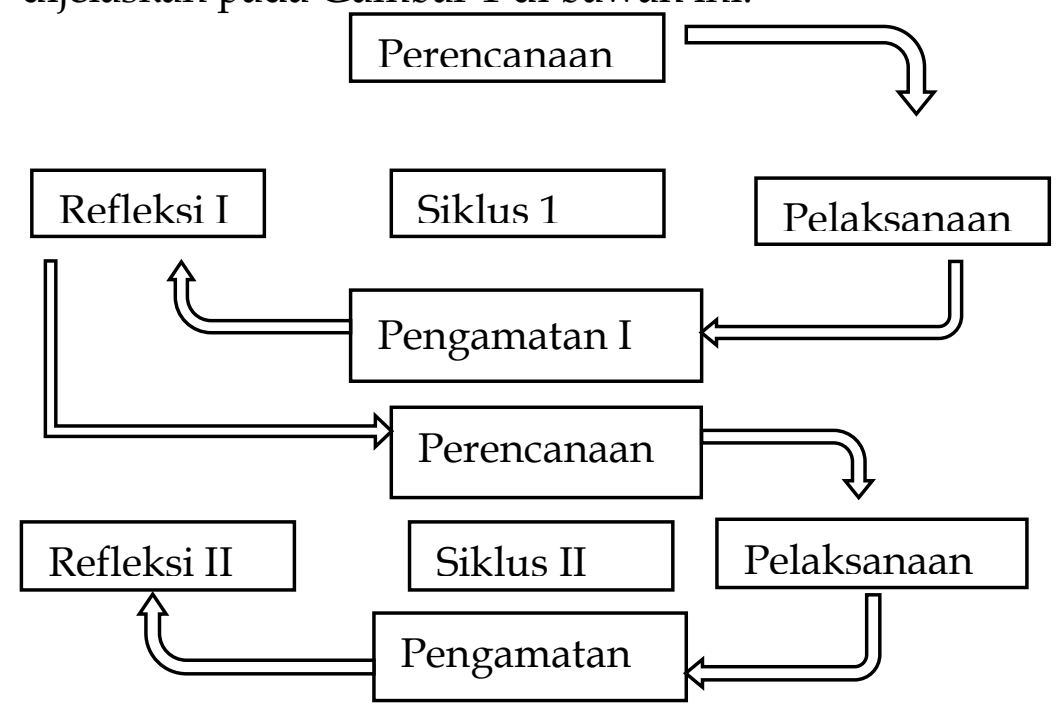

Gambar 1. Model Kemmis dan McTaggart (Taniredja dkk, 2013)

\section{HASIL DAN PEMBAHASAN}

Peneliti melakukan kegiatan penelitian tindakan di kelas XII IPA SMA N. 1 Wewewa Utara tahun pelajaran 2017/2018 pada pembelajaran matematika sebanyak 2 siklus. Siklus I terdiri dari 5 pertemuan. Siklus I dilaksanakan pada hari Rabu, 15 November 2017 (jam 5-6, 7-8) dan hari kamis, 16 November 2017 (3-4, 5-6) dan tes siklus I dilaksanakan pada jam 7-8 pada hari yang sama. Siklus II dilaksanakan pada hari Rabu, 22 November 2017 (jam 3-4 dan 5-6) dan hari Kamis, 23 November 2017 (jam 3-4 dan 5-6). Berdasarkan hasil tertulis diperoleh data yang selanjutnya direkapitulasi dan dianalisis berdasarkan kinerja guru dan hasil belajar siswa (kognitif) pada siklus I dan siklus II seperti disajikan pada Tabel 1 dan Tabel 2. 
Tabel 1 Rekapitulasi nilai kinerja guru

\begin{tabular}{llll}
\hline Kinerja Guru & Siklus I & Siklus II & Peningkatan \\
\hline Jumlah skor total & 107 & 145 & 38 \\
Nilai Kinerja & 66,88 & 90,63 & 23,75 \\
Kategori Nilai & cukup & Sangat baik & \\
\hline
\end{tabular}

Berdasarkan Tabel 1 dapat dilihat bahwa kinerja guru mengalami peningkatan pada setiap siklusnya. Siklus I memiliki nilai kinerja sebesar 66,88 dengan kategori "cukup" dan pada siklus II meningkat menjadi 90, 63 dengan kategori "sangat baik", terjadi peningkatan nilai kinerja sebesar 23, 75.

Tabel 2 Peningkatan hasil dan persentase ketuntasan klasikal belajar siswa.

\begin{tabular}{llllll}
\hline Siklus & Siklus I & kategori & Siklus II & Kategori & Peningkatan \\
\hline Rata-rata & 68,84 & cukup & 76,72 & baik & 7,88 \\
$\begin{array}{l}\text { Ketuntasan } \\
\text { Belajar }\end{array}$ & $61,11 \%$ & Cukup & $83,3 \%$ & sangat baik & $22,19 \%$ \\
\hline
\end{tabular}

Berdasarkan Tabel 2 di atas dapat diketahui bahwa nilai rata-rata hasil belajar siklus I adalah 68, 84 dengan kategori "cukup" dan pada siklus II mencapai nilai rata-rata 76, 72 dengan kategori "baik", terjadi peningkatan sebesar 7,88. Ketuntasan klasikal hasil belajar siswa siklus I sebesar 61, 11 \% dengan kategori "Cukup" dan terjadi peningkatan sebesar 22, 19 \% menjadi 83, 3 \% dengan kategori "sangat baik". Sudjana (2010) menjelaskan bahwa hasil belajar adalah kemampuankemampuan yang dimiliki siswa setelah menerima pengalaman belajarnya.

Berdasarkan hasil tes pada siklus 1 dan 2 yaitu pada siklus 1 diperoleh ratarata siswa sebesar 68,84 . Banyaknya siswa yang memperoleh nilai lebih dari atau sama dengan 75 ( $\geq 75)$ atau dapat dikatakan tuntas sebanyak 22 siswa atau mencapai ketuntasan klasikal sebesar $61,11 \%$. Jumlah tersebut belum mencapai target dalam meningkatkan hasil belajar siswa, jadi perlu diadakan siklus 2 untuk mencapai target yang diinginkan. Berdasarkan hasil tes siklus 2, diperoleh rata-rata siswa sebesar 76, 72. Banyaknya siswa yang memperoleh nilai lebih dari atau sama dengan $75(\geq 75)$ atau dapat dikatakan tuntas sebanyak 30 siswa atau mencapai ketuntasan klasikal sebrsar 83, 3 \%.Jumlah tersebut telah mencapai target dari indikator keberhasilan penelitian pembelajaran yaitu banyaknya siswa yang yang memperoleh nilai lebih dari atau sama dengan $75(\geq 75)$ atau dapat dikatakan tuntas minimal $75 \%$ dari banyaknya siswa kelas XII IPA dan tidak perlu diadakan tindakan lebih lanjut.

Berdasarkan hasil observasi kinerja guru pada siklus 1 dan 2, yaitu pada siklus 1 hasil penilaian observasi terhadap kinerja guru diperoleh skor rata-rata 66,9 dengan kriteria kinerja guru dalam pembelajaran cukup. Hasil penilaian tersebut belum mencapai target, sehingga perlu diadakan siklus 2 untuk mencapai target yang diinginkan. Berdasarkan hasil observasi kinerja guru pada siklus 2, hasil penilaian observasi terhadap kinerja guru diperoleh skor rata-rata 90,6 dengan kriteria kinerja guru dalam pembelajaran sangat baik. Hasil penilaian tersebut telah mencapai target dari indikator keberhasilan pembelajaran jadi dapat dinyatakan tuntas dan tidak perlu diadakan tindakan lebih lanjut. Secara umum proses pembelajaran yang berlangsung pada setiap siklus sudah berjalan dengan baik, hal 
ini ditunjukkan dengan semua tahapan yang ada dalam pembelajaran melalui penerapan model PBL sudah dilaksanakan dengan baik.

Hasil penelitian yang telah diuraikan menunjukkan bahwa indikator keberhasilan telah tercapai. Ada peningkatan hasil belajar siswa dalam kegiatan belajar melalui penerapan model PBL pembelajaran siswa kelas XII IPA SMA N 1 Wewewa Utara.

\section{KESIMPULAN}

Berdasarkan hasil Penelitian Tindakan Kelas (PTK) yang berkaitan dengan tujuan penelitian, dapat disimpulkan bahwa penerapan model Problem Based Learning $(P B L)$ dapat meningkatkan hasil belajar siswa pada materi program linear di Kelas XII IPA SMAN 1 Wewewa Utara. Hasil belajar siswa secara keseluruan pada siklus I sebesar $61,11 \%$ sedangkan pada siklus kedua mengalami peningkatan menjadi $83,3 \%$ dan telah mencapai indikator ketuntasan minimal (75\%) serta mengalami peningkatan dari siklus I ke siklus II yaitu sebesar 22, 19\%.

\section{SARAN}

Siswa diharapkan untuk lebih aktif dalam mengikuti kegiatan pembelajaran sehingga dapat mempermudah dalam memahami materi pembelajaran agar mendapatkan hasil belajar yang maksimal, membiasakan diri dalam mengemukakan pendapat, dan bekerja sama dengan siswa lainnya ketika berdiskusi kelompok. Tentunya diimbangi dengan semangat belajar siswa yang akan memperkaya ilmu pengetahuan dan wawasan. Guru kelas diharapkan dapat menggunakan variasi model pembelajaran yang lainnya, tidak hanya model pembelajaran PBL. Model pembelajaran yang dapat mengembangkan kemampuan berpikir dan berkomunikasi. Sekolah hendaknya memberikan fasilitas pembelajaran yang memadai, serta sarana pendukung untuk melaksanakan perbaikan pembelajaran demi meningkatnya mutu pendidikan di sekolah. Penelitian ini mengkaji penerapan perbaikan pembelajaran dengan menggunakan model PBL.

\section{DAFTAR PUSTAKA}

Baskoro, W. (2006). Kamus Lengkap Bahasa Indonesia dengan Ejaan yang Disempurnakan Edisi Lux. Jakarta: Setia Kawan Press.

Dewantara, A. (2008). Rumus Kantong Matematika SMA. Yogyakarta: Pustaka Widyatama.

Dewi, C.A. (2013). Pengaruh blended learning dalam pembelajaran berbasis masalah (pbl) terhadap hasil belajar mahasiswa IKIP Mataram pada materi pencemaran lingkungan. Prisma Sains : Jurnal Pengkajian Ilmu dan Pembelajaran Matematika dan IPA IKIP Mataram, 1(1), 1-11. doi:https:// doi.org/10.33394/jps.v1i1.514

Hermeliyati, P. (2016). Pengembangan lembar kerja siswa pada materi program linear dengan model pembelajaran berbasis masalah (tesis).Diakses dari https://id.123dok.com. 14 September 2017.

Idris, S. (2016). Peningkatan hasil belajar program linear melalui strategi pembelajaran Inkuiri dan Geogebra siswa kelas XII IPA ${ }^{1}$ SMA N 1 Tompobulu. Diakses dari idealmathedu.p4tkmatematika.org. 14 September 2017. 
Irawati, S. (2015). Analisis kesalahan mahasiswa calon guru matematika dalam memecahkan masalah program linear. Diakses dari ejournal.unira.ac.id. 14 September 2017.

Meilani, R., Hunaepi \& Mirawati, B. (2017). Pengaruh Model Pembelajaran Berbasis Masalah dengan Pendekatan Saintifik terhadap Keterampilan Berpikir Kritis Siswa. Prisma Sains : Jurnal Pengkajian Ilmu dan Pembelajaran Matematika dan IPA IKIP Mataram, 5(1), 20-24. doi:https://doi.org/10.33394/j-ps.v5i1.1153

Okayana, K. (2015). Penerapan model problem based learning (PBL) untuk meningkatkan aktivitas dan hasil belajar matematika pada siswa kelas IV SD Negeri 3 Metro Barat tahun ajaran2015/2016. Diakses dari digilib.unila.ac.id. 18 September 2017.

Pasaribu, R.V. (2015). Penerapan model problem based learning (PBL) untuk meningkatkan aktivitas dan hasil belajar matematika pada siswa kelas XI SMA Negeri 1 Semarang (penelitian PTK) tahun ajaran2015/2016. fisikawansastra. Diakses dari blogspot.com. 18 September 2017.

Prayogi, S., \& Asy'ari, M. (2013). Implementasi model PBL (problem based learning) untuk meningkatkan hasil belajar dan kemampuan berpikir kritis siswa. Prisma Sains : Jurnal Pengkajian Ilmu dan Pembelajaran Matematika dan IPA IKIP Mataram, 1(1), 80-88. Retrieved from http:/ / ojs.ikipmataram.ac.id/index.php/prismasains/article/view/521/485

Shoimin, A. (2014). 68 Model Pembelajaran Inovatif dalam Kurikulum 2013. Yogyakarta: Ar-ruzz Media.

Sinaga, B., Sinambela, P.N.J.M. (2014). Buku Guru Matematika SMA/MA/SMK/MAK Kelas XI. Jakarta: Pusat Kurikulum dan Perbukuan, Balitbang, Kemdikbud.

Siswanto. (2005). Matematika Inovatif Konsep dan Aplikasinya. Solo: Tiga Serangkai.

Sukaisih, R., \& Muhali. (2014). Meningkatkan kesadaran metakognitif dan hasil belajar siswa melalui penerapan pembelajaran problem solving. Prisma Sains: Jurnal Pengkajian Ilmu dan Pembelajaran Matematika dan IPA IKIP Mataram, 2(1), 71-82.

Taniredja, H., Tukiran., Pujiati, I. (2013). Penelitian Tindakan Kelas untuk Pengembangan Profesi Guru Praktik, Praktis, dan Mudah. Bandung: Alfabeta.

Tirtarahardja, U. (2005). Pengantar Pendidikan. Jakarta: Rineka Cipta. 